
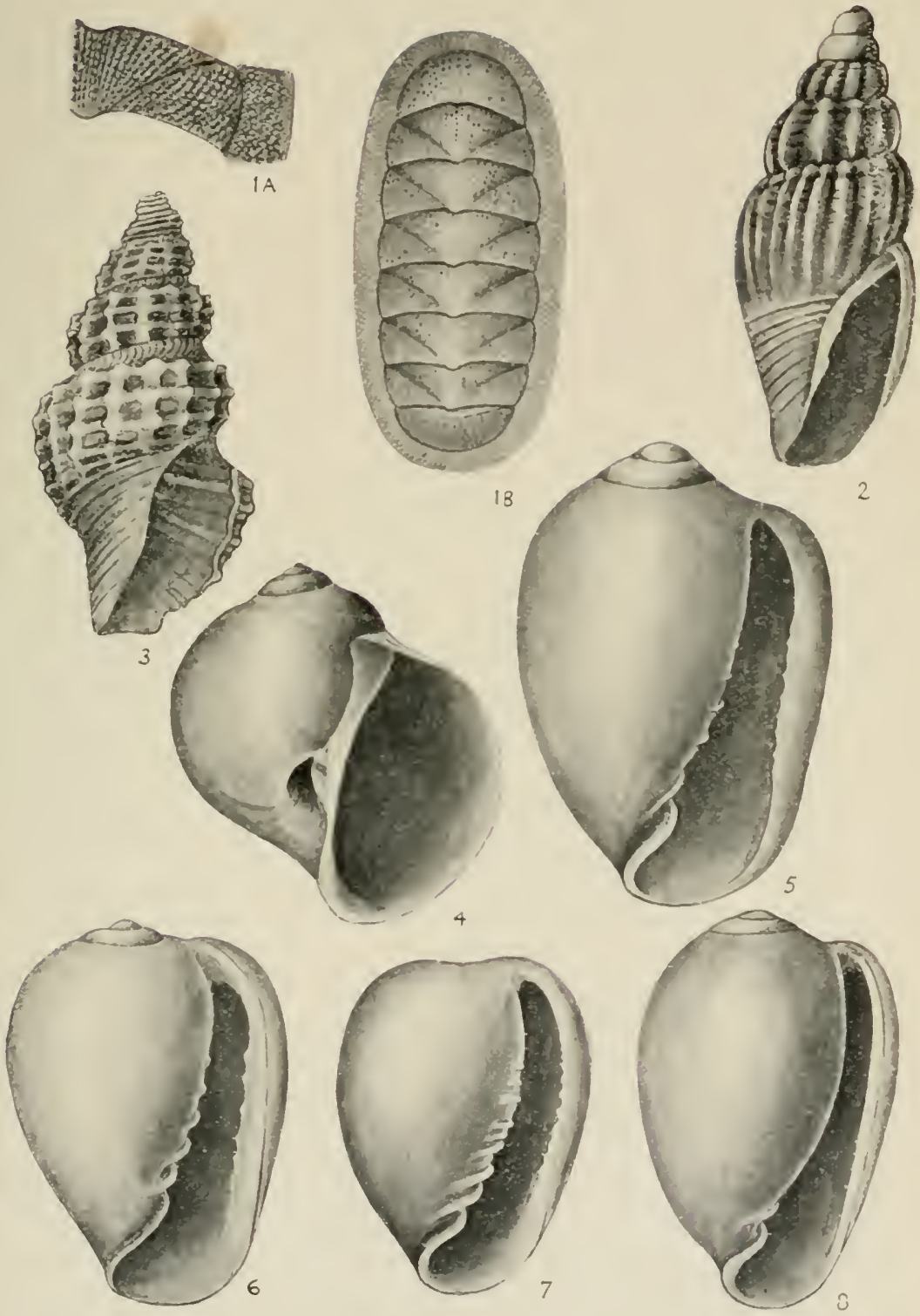
NEW SPECIES OF TASMANIAX MOLLUSCA, WITH CRITICAL REMARKS ON SEVERAL DESCRIBED SPECIE- AND ADDITIOA: TU THE LIST.

\author{
BY IV. L. MAY,
}

(Received 20th Junc, 1219. Read 11th August, 1919.)

\title{
Plates NIV.-NYII.
}

The species here de cribed include no startling noveltics, but are more or lese closely related to previously known forms. They liave come from varion-parts of our (waste, and from liw water mark down to onc hundred finthoms, and mav be described as the bolince irom several rear i collecting left after monc striking speres have been dealt with. The trope of the new species will bt presented in the Tasmanian Mlu-eum.

$$
\text { Ju11:. } 1919 .
$$

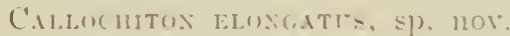

Sledl very small, narmwly elongats, sirile rather broad ; ratler elevated : the valves cli-tinctly beaked.

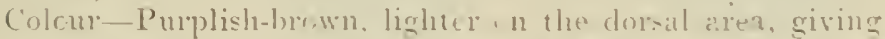
the appearance of a lomgitudinal pale bund A ro-type has the 6th and 7th valies mostr pale green and the ond valve with a large whitish hlotele dorsally.

Anterior valve emi-cireular, slighty berticd, covered witle minute pu-tules; median valves with latcral areadistinctly raised. the pleural and dorsal arias ate not s-parated, except that the low pustules that icrer the whele valve become. fine and more longiturlinal towards the ridge. Tail valve with mucro about onc-fumth from the adjoining valve differentiated trom the rest of the valve $b y$ a small ridge and rery slighty clevated. Crirdle

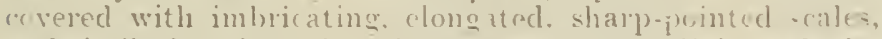
and similarly colomed to the valve, hut cf a lighur shade, sometimes with paler hlotehes.

Length 7.4 : beacith, 3.6 mill.

Habitat Norfolk Bav and Poit Arthut (E. Mawle). - ven or eight spocimens crollected. This l cautiful little species is a very mull smaller and normonr shell than $C^{\prime}$.

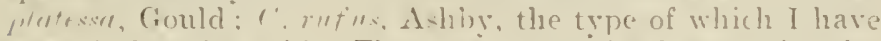
s. 11, is lnoader still. The present specie- ha-for its size wareer sculpture than plotesse. It ravies much in colour- 
ing, but the ground colour seems always to be some shade of purplish-brown. It may be blotched with green and whitish in various degrees of pattern.

Pl. XIV., figs. $1 \mathrm{a}, 1 \mathrm{~b}$.

\section{Apaturris costifera, sp. nov.}

Shell small, fusiform, white with a broad chestnut band on the contre of the Lody-wherl. Whorls $5 \frac{1}{2}$ rounded. the first two being quite smooth, the rest sculptured with strong, rounded axial ribs, fourteen cn the penultimate. sixteen on the body whorl, they fade away a little below the periphery. The base being encircled by numerous fairly strong spiral lire: the ribs are crossed by very fine, sharp spiral threads. Aperture fairly large, pointed above, broad at the base, where it scarcely becomes a canal; columella excavate, bearing two low tubercles, onter lip rounded and simple.

Lcngth, 4.5; breadth, 2- mill.

Habitat. Trne, with five other's from about 40 fathoms East of Thouin Bay.

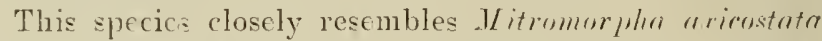
Verco. It is, however, a narrower shell, with more rounded whorls, and the spiral lire are much less strong; it has, too, as more bluntly rounded apex.

Pl. XIV., fig. ?.

\section{Nepotilla diaphana, sp. nov.}

She:ll small, thin, of a semi-transparent texture, colour yellcwi-h-brown, pinkish towards the apex, broadly fusiform, whorls five, including a prominent two-whorled proteconch, which is strougly spirally lirate; the aduit whorls much rounded, and strongly cancellate. There is a hcllowed space below the suture, corresponding with a shallow sinus, and ornamented by curved growth lines; strong axial ribs cross the whorls and are separated by spaces of about their own width: they number abcut twenty on the body whorl and fade away below the periphery; they are crossed on the spire by three spirals, less strong than the ribis and abont equally spaced, so that square meshes are formed, producing simall nodules at the junction. These spirals continue on the base, where they are smaller and clcser together. Ape:ture broad, with a verv short open canal, columella excavate, with a narrow callous lip, outer lip rounded, corrugated by the sculpture, with a broad rather shallow sinus at the suture.

Lcngth 4.4 ; breadth, 2 mill. 


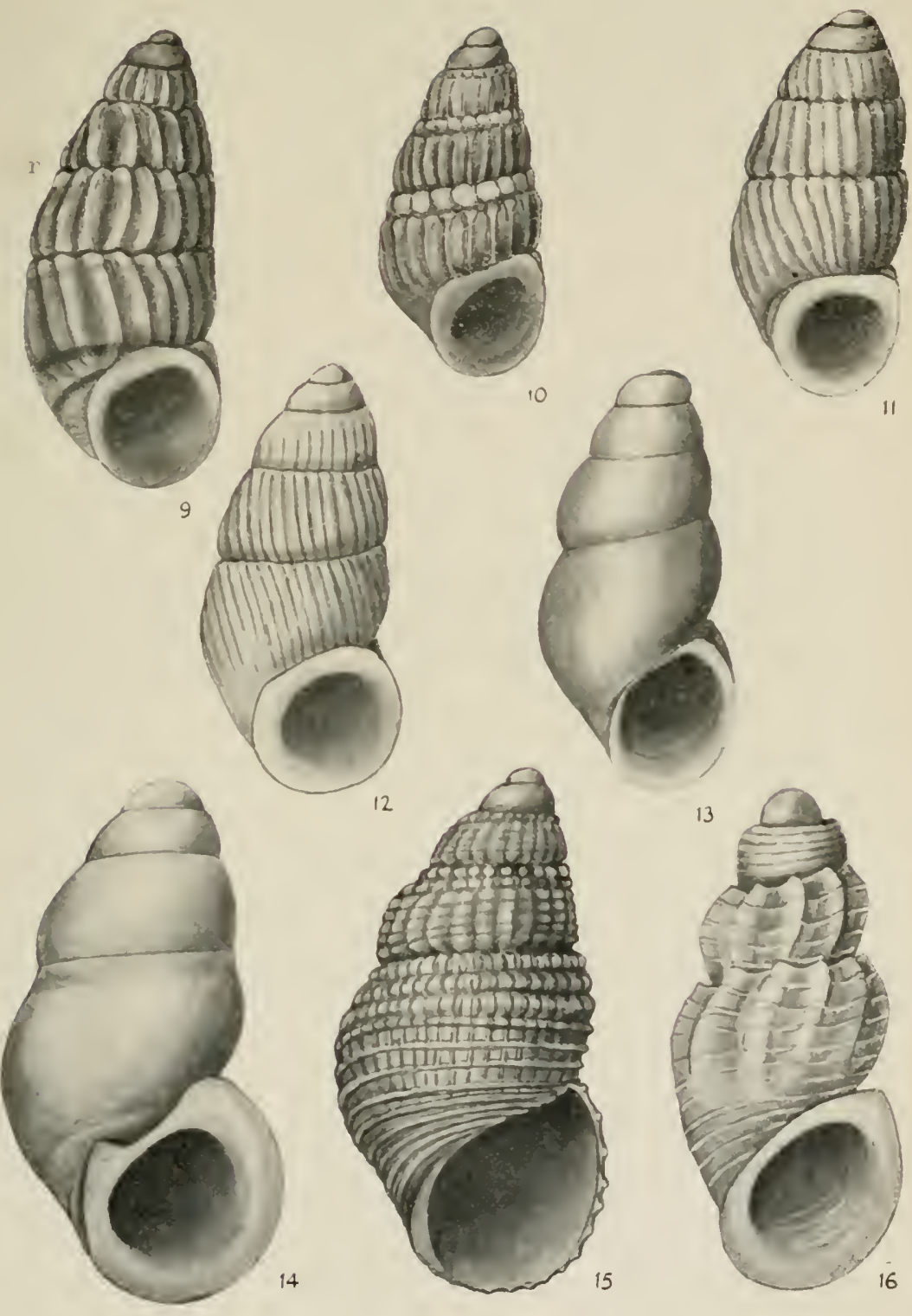


Habitat. The type, with five others from Frederick Henv Bav, two others from Thouin Bav, Ea-t Coast. 1]l the specimens lave be en taken fiom the ruots of the giant kelp and have much the appearauce of young shells.

It rescmbles 1 . lermmli, Beddome, more than any cther, but is cntively distinct from that species, which is inurli more strongly sculptured, and has many more soirals.

Pl. IIV, 6g. 3 .

Polinifes catexoldes, sp. nov.

Shell of moderate size, rotmel. with a small hut sharp? spire: umbilicate. Whorls nve, rapidly increa-ing. the last. vary larep, rounded. With a slight depression lelow the suture. Aberture roundly lunate, satler proluced in foont. lip thun. Columella a little concave, with a callus lant] covering the umbilicus. and fleveloping into a pad where it joins the lip above: the callu-i has a distinct woove crosing it, at the upper colge of the umbilicus, which latter is of mockrate size. cleep and perspective. The eclour appears te be yellowish-brown, pale how the suture, and on the bass, and there ale indications of chestnut flames crosing the - utural bancl, and pateles of the same colour on the boty whorl. Dianeter anei beight, ealt 1.) 1011 .

Type witl 10 other, most!y small, fro.n about 60 fathom: Soutle of l'on Arthur and one from lon fathoms Eas: of C'apre l'illax.

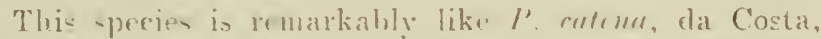
from Northen Emope, -c much - o, that it is at first difi.ult to s : anv differuces. However. the umbilicus is rather -mallex, and the fromt of the columella more produced: it is rather liscalen, has a depression below the suture, a furrow on the columella. and probably the: colour is different. Compred with l'. "ulureflesser, Pils. and Van., it is a much rounder shell, and lacks the heary mad over the umbilicu. besides be ing much smaller. I have known this speries ine a comsicleralle time. but hesitated to describe it, loping fer hoter examples; such, howevel, have not yet come to hamel. 11 my specimens are "drad, and most have lost their colour, hut some - how traces of coloration as above lescribed. It is pos"ihle it reaches a consiclerably latege size, as nome of mine appear to be ruite achult. Its etation world ammear to be flom about jo to 100 fathoms.

Pl. XIV., fig.. 4. 


\section{Marginella obesula, sp. nov.}

Shell very small, broadly ovate, transheent white, witly a distinct, but blunt spire of two whorls. Aperture narrow above, but widening rapidly towards the rounded front. Columella convex; the first plait, which is a continuation of the front of the shell, is large, strong, and curved. The next above is much smaller and rather elose to the first, above are four minute plaits, which reach quite two-thirds up the columella. Outer lip thickened, incurved in the middle, where it is armed with about nine minute teeth.

\section{Length, 2: breadth, 1.1 mill.}

Types, with six others, from Frederick Henry Bay, one otler from Port Arthur. Whilst this resembles such relatives as $1 /$. shorehmmi, Prit. and Gat., it neverthelcss has some good points of difference, and these are emphasised by the rery peeuliar animal, which, showing through the translucent shell, exhibits a bright orange colour, curiously netted with white lines, each bordered with black, empty shells show no traces of this pecnliar ornamentation, which must belong to the animal. In our other small speeies the animal usually appears black or horny.

The habitat is also peculiar. Most of the speeimens have been taken from roots of the giant kelp, showing it to inlabit rocky bottoms.

Pl. XIV., fig. 5.

\section{Marginella ringens, sp. nov.}

Shell very small, broadly pyriform, pure white, semitransparent, with an exsert, but very small spire of two whorls, which has a tilt towards the right. Aperture broad, especially towards the rounded front. Outer lip solid, shouldered, and much curved above, but straight on its inner sicle, where it bears abont six small denticles rather irregular in size and spacing. Columella convex, but rather straight in its middle part, and carries about six plaits, of which the first is a long, upward sweep from the hase; the next two are well developed, those above being much smaller.

\section{Length, $1.8 ;$ breadth, 1.2}

Type from Kelso, Tamar Heads, collected by the late Ang. Simson; another exactly sinilar from the Petterd collection, probably from the same locality ; and eight others from 40 fathoms off Thouin Bay, which differ slightly in having more minute denticles on the lip, but are otherwise the same. 
This is very close to $M$. angari, Crosse. of which it may be a variant. It is more broadly shouldered, with a larger aperture, and has the toothed outer lip.

Pl. XIV., fig. 6.

Marginela MLLTidextitA, ap. nor.

Shell small, white, broadly-orate, spire hidden, aperture rather wide. Columella convex, hearing about nino main plications, of which the anterior three are the strongest; there are sereral small subsidiary tecth between the upper ones. Onter lip rires above the summit; is strongly thickened and armed inside with about ten minute denticles.

Length, 1.5; breadth, 1.2 mill.

'Type. with three others from about ten fathoms, between Gordon and south liruny, DEntrecateans Channel.

This species is nearest related to $1 /$. throminensis. May; it differs in being horter and broader, having a wider aperture, stronger clentition, and threnated outer lip. The small intercalated teetl have not been nuticed in any of her Ta:manian Marginella.

Pl. XIV., fig. $\tau$.

\section{Mancinela mererta, sp. nor.}

Shell minute, smooth, white, opaque, ovate; spire small but distinct, of two whorls. Apterture nimow abore, almost linear for half its length, then widening to the romuded front. Outer lip moderately thickened, slightly curved, smontl within. Columella convexly rounded, with two distinet plaits, rather near together, of which the anterior is the sturnger.

Length, 2: breadth, $1.6 \mathrm{~mm}$.

Type, with five others, from about 40 fathoms of

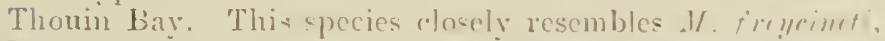
May, in size and shape; it has more spire, is broader, with a more curved columella, and only two plait.

Pl. XIS., fig.

Iredale in Trans. N.Z. Tust. for 1914, p. 4.5 T, projumed a new genus listen for a Ri-soid gromp, and nemtions Riswem colmmurm, Hedley and May, a- a good reprecentative. We have a large number of specion, which seem io fall naturally into Iredale's genus. Thiere are some s-venteen Tasmanian named speeies, and others not yet 
described, that I can so place, only two or three of which are somewhat abberante. Amongst them is a little subgroup of four species, closely allied to each other, upon which I now offer some observations, describing one as new.

\section{Estea TUMIDA, Tenison Woods.}

Described in these proceedings for 1875 , p. 147 , as B)inln tumirlu, a figure was given by Tate and May for this species, Pl. xxvi., fig. 67, which, however, is not correct, but represents a nearly related species, which I am dealing with later.

A careful examination of the types (two specimens) preserved in the Hobart Musemm, and which are very bleached, show it to be a gcod species, and of which I have taken a fair number of specinens, always from the roots of the giant kelp; fresh shells are of a pinkish tinge, and have a narrow chestnut band below the suture, and two on the body whorl, one at the periphery, and the other on the base. Theae bands are characteristic.

The ribs are also broad, strong, and oblique. I present a figure from a specimen compared with the type.

Pl. XV., fig. 9.

\section{Estea olivacea, Dunker (Risisur).}

Ris.sur diemenensis, Petterd, is an absolute synonym. as Tate and May correctly determined, the type being preselved in the Hobart Museum. This species differs from E. tumidre in its more squat shape, and more numerous ribs, which are narrower and straight; they also form a nodular bead below the suture. It is common at Tamar Heads, but seems absent from the South, where its place is taken by the next species.

Pl. XV., fig. 10 .

Estea kershawi, Tenison Toods (Risonina).

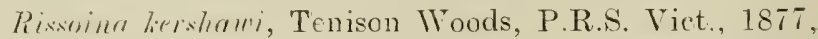
p. 57. This was mited with E'. tmmill, by Tate and May, but examination of the types in Melbourne Musem shows it to be a distinct, but closely related species. It lias three adult whorls, instead of four, the ribs are straighter, and much more numerous, and the mouth is not so round, and it lacks the colour bands; the usual colonr is yellowishbrown, with a pale band below the suture. It is found in the Derwent Estuary and D'Entrecastcaux Channel, and is common at Tamar Heads, with $E$. olinacea, which it closely 
resombles, but may he distinguished by its more crlindrical form, mole numerous ribs, and the absence of the sutural bead.

Pl. $\mathrm{XI}^{\mathrm{T}}$, fig. 11.

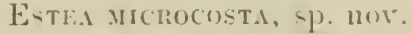

Shell small, rather pupoid, solid, pinkish. the apical whorls are the darlest, the last half of the body whorl noaly white. Whorls five, rounded. The first wo form a smooth proto-comeli: the three adult whorls are regularly avially ribbed. with rory fine shapp ribs, which are sompwhat oblique, and bione evanestent con the hase. Aped'ture almot roumd. lip expanded all round.

Length, 2.5: breadth, ].2 mill.

Type, with a number of others, from loo fotloms steven miles bast of ('ape l'illar. This is r lesely related to E. Levelent. It differs principally in the imuh mowe mumerous and finer ril, and romeler mouth, and its rather

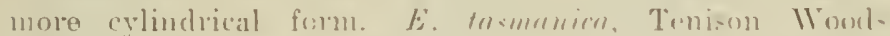
(Eulimu), is much larger, mote pramidal, with cexcalvate sutures.

Pl. XY., fig. 1:.

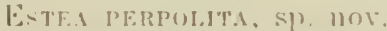

Sincoll smali, whitu. highly poliched, clrongate, hlumt. the apex boing murle thattoncil. Whorls foul and a lialf. remede esperially the pemultimate; suture wall impreseor: moutl roindly ovite, lip a good deal expanded.

Length, 1.8: breadth. I mill.

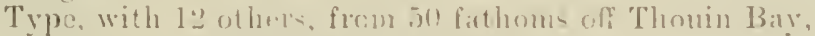
and three from lou fathom off ('ape Jillat.

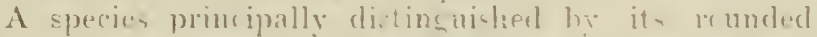
whorls, flattened sumuit, and hish poli-h. and riffer- from

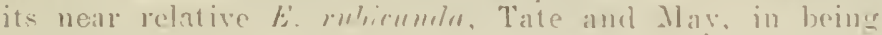
slorter and blunter.

Pl. $\mathrm{XV}^{\mathrm{T}}$, fig. l::.

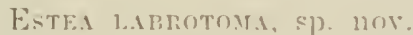

Shell minute. inical, solid, vellewi-h-bouwn, consoth, shining. Whorls four, roundwl, silsure woll impreased, the body wherl being rather restrieted below the sutur. Aperture roumbly ovate, oblique, smromuded by a very broad expanted lip, which has a curious chep inclentation where it joins the hody whorl. This romarkablo feature is diagurstic.

Length. 1.1; hreadth, . $\overline{\text { mill. }}$.

Type, with 1.1 otlers from Freclerick Henry Bar, taken from roots of the giant kelp.

Pl. XI., fig. 1.1. 
Merelina sculptilis, sp. nov.

Shell solid, broadly ovate, cream coloured, imperforate; whorls five, rounded, the first two forming a smooth proto-conch. Suture well defined by a deep channel. The adult whorls: are crossed by radials, which are strong, and predominate on the two upper whorls, but grew finer and much more numerous on the body whorl. These are crossed by spirals, which from being at first inferior, become on the body much the stronger. The body whorl carries about thirteen spirals, of which the upper three are large, rounded, and noduled by the axials. The lower snirals are narrow, and scarcely affected by the ribs, which fade at the peliphery. Seven spirals cross the ribs on the middle whorl. of which the one above the lower suture, and the two below the upper suture are the stronger, the latter forming rows of nodules: the third whorl is similar. Aperture ovately-pyriform, the columella, which is not continuous, is rather expanded anteriorly; outer lip thin, dentated by the sculpture.

Length, 3; breadth, 1.5 mill.

Type, with three others, from 50 fathons off Thonin Bay.

Frcm its nearesi relative $R$. filurincta, Hedley, it may be clistinguished by its flattar whorls, much more numerous axials, the strong beaded spirals on the shoulder, the chamnelled sutures, the discontinuous peristome, and the sharp outer' lip.

Pl. XV.. fig. 15.

Hatrakia supracostata, sp. nov.

Shell small, rather elongate, yellowich white, semitransparent; whorls four, rounder, stuture deeply inpressed. The apical whorl is small, dome shaped, and simootll; the next is tabular and finely spirally grooved; the last two axially ribbed with strong oblique ribs, which bend towards the left at the suture. There are about six cn a half-turn of the whorls; they facie away below the periphery, and are crossed by fine distant lire, which are scarcely raised, and show as white opaque lines on the translucent shell. Aperture roundly pyriform, lip expanded and continuous, projecting beyond the whorl postericrly.

Length, 1.7 ; breadth, .8 mill.

Type, Frederick Henry Bay, taken from a root of the giant kelp. Three others from 40 fathoms off Thouin Bay: 

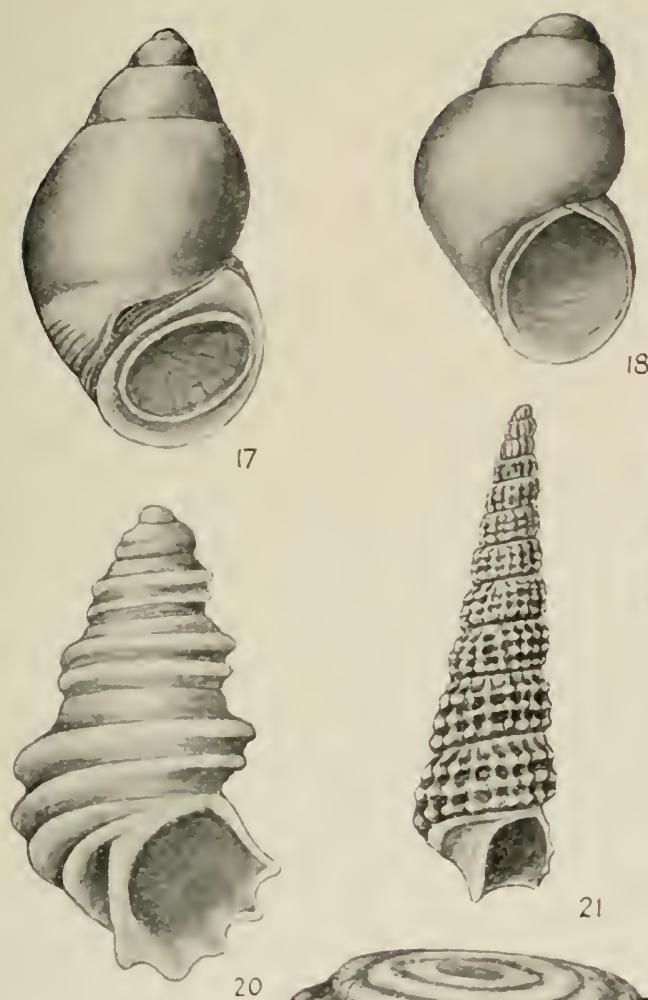

18
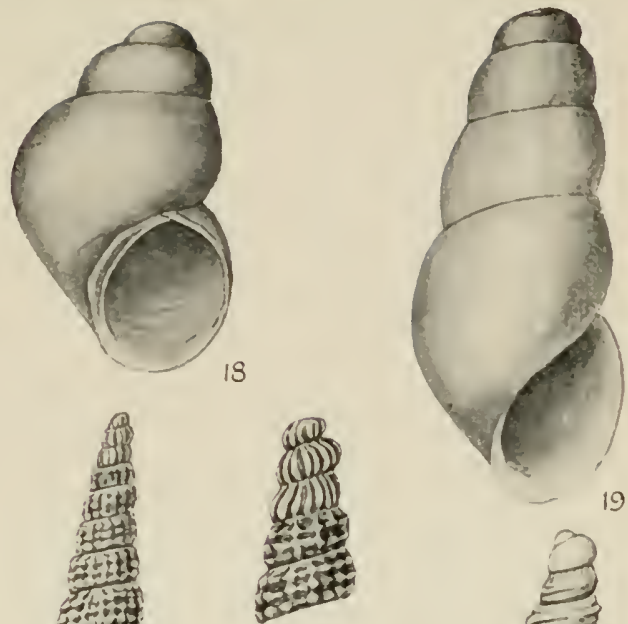

a
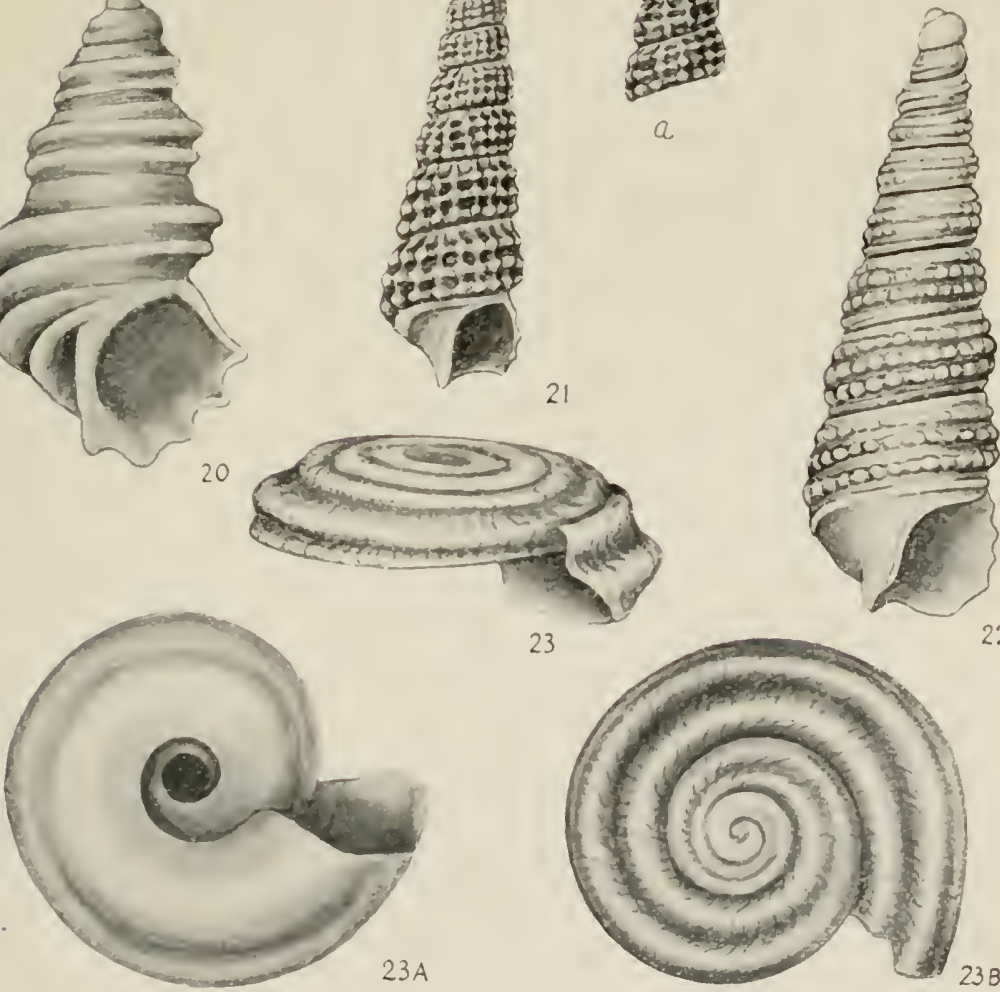

23

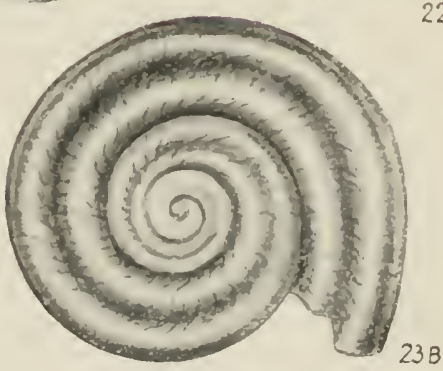


a very clistinct little species. I plare this in I/murulin with some diffidence, but it secms to come closer to such species as $/ /$. strungri than any other forms.

$$
\text { Pl. XY., fig. } 16 .
$$

\section{Amputhalantes Letrofescus, sp. nov.}

shell minute, turbinate, smooth, lustrous recl-brown, with the first half of the body whorl and mouth, yellow, also a light band below the suture. Whorls four, much rounded, body whorl large in proportion. Aperture: The actual opening is small, oval, and set very obliqucly to the spire; it is surrounded by a raised edge or keel. The peristome, which is eontinuou, is broadly protiform. expanded and planulate, rectsed towards the aperture: it is projected somewhat from the bare of the shell, which is sub-umbilicate. The 'perculum is thin, seni-transparent, and appears to be subspiral.

Length, 1; breadth, .6 mill. .

Habitat. Type, with screral others from lielso, near Tamar Heads, collected by Augustus simson.

This minute sliell is in sizo and general appearance similar to .1. jorkstem, Brizier, but differs sufficiently in the detaile of the mouth, and also in the coloration; it is

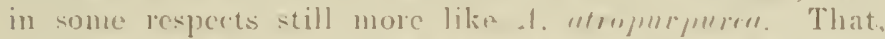
however, is a muel mole ventricose and massive shell, which dors not seen to have bern heretofore recognised as a momber of this genus, althougly it is extremely characteri-tic, and closely allied to .1. jurkmmi.

PI. XVI., fig. 17.

\section{Nutosetil perperEostuM, sp. nov.}

Shell minute, hluntly turbinate, smooth, polisherl. pale rose colom, lip rose-purple. Whorls three, much reunded. suture impresed. Aperture, rourdly oval, lip continuous, with a thickened edge, and reflexed on thr eolume lla sicle.

Longth, 1; breadth, .\& mill.

Type, with a dozen others. from Penguin, in shell sand. It has a superficial recemblance to imphithatrimus atrommrnum. Fraucnenfelt, from which the latter's typical aperture at once separates it.

PI. XYI., fig. 18.

RISSOPSIS BREYIS, Ap. nov.

silucll very small, eylindrical, blunt, smooth, puro white, pellucid. Whorls, four and a halt, rather rounded, 
suture impressed, apical whorls much flattened. Aperture pyriform; outer lip thin and sharp, somewhat expanded anteriorly.

Length, 2; breadth, :8 mill.

Type, with two others, from 40 fathoms off Thoum Bay, one other from off Arch Island, D'Entrecasteaux Channel.

I place this with Rissupsis, as it seems congeneric with the species assigned to that genus by Professor Tate, a location which I think recinires confimation.

Pl. XVI., fig. 19.

\section{Lippistes CONSOBRINA, sp. nov.}

Shell small, whitish, smooth, pyramidal, umbilicate. Whorls four or five, including a smooth proto-conch of about two turus. The adult whorls are encircled bv rwo strong keels, the upper of which is the larger, and is a little above the centre of the whorl. These keels are separated by a furrow of about their own width. There aro two additional keels on the base, the anterior of which encircles the umbilicus, which is deep, but rather narrow, and separated from the aperture by a strong columella pillar. Aperture roundect, outer lip strongly dentated by the keels.

Length, 3 ; breadth, 1.5 mill.

Type, with three others, from 40 iathoms three miles East of Schouten Island.

In these proceedings for $1910, p$. 309, I recorded this species as $I$. yracilenta, Brazier. I have since had an opportunity of examining Brazier's type, which shows that the two forms are specifically distinct, graritenta being much larger and more attenuate in the spire. Our shell comes between this and $L$. zirliurus, Hedley, which is similarly sculptured, but is only half the length, and has a different apex.

P1. XVI., fig. 20.

\section{Cerithiopsis apicicosta, sp. nov.}

Shell small, elongate, or narrowly pyramidal, whitish. Whorls eleven, including a three-tworled proto-conch, which is strongly axially ribbed. Adult whorlo moderately rounded, suture well impressed; sculpture, three nodulons kecls of about equal size and distance encircle the whorls. They are separated by a deep groove, across which the nodules are connected by low axial ridges. There is a 
smooth keel on the base, which is otherwise plain. Aperture subquadrate? (rather broken), with a short anterior canal. Outer lip dentated by the sculpture.

Length, 7 ; breadth, 1.6 mill.

Type, from 100 fatloms seven milcs East of Cape pillar. Several others, mostly juvenile, from about 40 iathoms off Thouin Bay. This species is rather nearly related to ('. trisculptu, May, which was described from a half-grown shell. It is narrower, with weaker sculpture and a different, though somewhat related proto-conch, which seems to separate it from all other species.

PI. XVI.. figs. 21, 21a.

\section{Cerithiopsis Manhla, sp. nov.}

Shell small, pale brown, prramidal. I'horls nine and a half, rounded, inclucling a simooth, bulbous proto-conch of about two whorls. Aelult sculpture consists of three main keels, which are more or less nodulous, the central one being rather the largest. They are separated by equal sized, smooth spaces. There is a small smooth keel below the others, which shows very distinctly on the base, which is smooth. Aperture subquadrate, inner lip very concave, outer lip dentated by the keels. There is a short anteriol canal. The kecls on the upper whorls are almost or quite smooth. As growth proceeds they become faintly, irregularly nodulous. On the three last whorls the nodules are more distinct.

Length, 5: breadth, 1.4 mill.

Type, with ten others, from about 40 fathoms off Thouin Bay, East Coast.

Whilst the shape of the shell is fairly constant, and the pullus always the same, co-types show considerable variation in the sculpture; whilst most are similar to the type, they may be almost destitute of nodules, or there may be three strongly nodulous keels on all tho adult whorls.

Pl. XVI., fig. 22.

\section{Orbitestella inedalei, sp, nov.}

Shell minute, discoidal, smooth, white, spiro flat. Whorls about three and a half, square in section, bicarinate, the upper carina at the angle being the largest, and forming a spiral keel on the flat summit to the apex. The flattened part of the whorl between the angle and the suture is roundly elevated; base margined by the lower keel, otherwiso smooth except for lines of growth, which are in evidence over the whole shell, broadly, per- 
spectively umbilicate to the apex. Aperture roughly quadrangular, wider than the height of the shell; at the outer edge bidentated by the keels.

Diameter, 1 ; height, about .4 mill.

Type, with a few others, from Frederick Henry Bay, taken from the roots of the giant kelp.

This minute shell has a considerable resemblance to ''yclostrema lustowi, Gatliff, the type of Ortitestella, and I consider it congeneric; probably $C$. mayii, Tate, should also bo included in this genus.

Note.-The specimen from which the drawings were made was accidentally destroyed.

Pl. XVI., figs. 23, 23a, $23 \mathrm{~b}$.

\section{Patelloida corrodendi, sp. nov.}

Shell roundly ova?, rather depressed, apex one-third from the anterior end, exterior furnished (in the type), with 20 radiating, snooth ribs, irregularly spaced, which extend from the summit to the margin, and several shorter ones, intercalated near the margin. The ribs are but slightly raised, dull white, the wicler interspaces being black, apex eroded. Interior margin black, bearing white triangular spots opposite the ribs, with their sharper points towards the edge. Behind these is a narrow purplish ring, then bluish, with a brownish-white centre.

Length, 14; breadth, 11; height, 5 mill.

Type, from the western shore of Frederick Henry Bay.

While fairly constant in shape, it varies much in the number of ribs, sometimes boing nearly twice as numerous as given above. The shell is often so much corroded that the sculpture only remains on the marginal third. The species is common at a spot near my home living on large diabase boulders, at about half-tide. $Y$ have not yet noticed it elsewhere; it long escaped notice, as it is associated with Siphonarin tiemenensis of about the same size and general appearance. As thev are exposed to the air for several hours at every tide, they suffer extrsmely from erosion, even quite small ones being badly affected. It resembles P. flammea, Quoy and Gaim, in general shape. That species is destitute of ribs, but has fine axial strix, and a different interior colocation, and lives near low water mark.

Pl. XVII., figs. 24, $24 \mathrm{a}$. 
C'OCCLLINELLA TASMANICA, Sp, HOV.

Shell small, white, thin, smooth, narrowly oval, pyramidal, apex subcentral, margin much raised at each end. There is no seulpture, except faint growtl lines.

Length. 5: breadth. 2.6; height, 2 mill.

Type, with a number of others, from forty to seventy fathonis along the East Coast.

This species is a near ally of $C^{\prime}$. compresse, Suter, from New \%ealand, and $C$. ciscrito, Hedley, from New south IVales. It is nearce the former, which is rather narrower, higher, and has fine radial sculpture. The latter is narrower. flatter, and lias an almost flat base. Probably they are loeal forms of one variable species, in which perhaps some peculiarity in their places of attachment has determined the form of the base: straiglit in one case, much curved in the others.

All the specimens taken hav" been "dlead" shells, but there are indications that in life they would be glassy and semi-transparent.

Pl. XVIT., fig. 25.

Elluma apheres, Tenison Moods.

Described in these proceedings for 1STS, p. 40.

The true was missing for many years, but. was lately discovered, having been mi-laid in the Tasmanian Museum. I here present a figure from the type, which is so marked by the author. I consider it to be an absolute synonym of Eillime aurur, Angras.

Pl. XVII., fig. 20 .

\section{Eclima marginati, Tenison Woods.}

Described with the last and also reenvered with it, and marked as type by the autlor. This specimen I havo also figured. It is given by Tate and Mav, P.L. Soc., New Sonth Wales, for 1901 , p. 3S1, as a prioi name for siylifer lodlerer. Petterd. This identification was incorrect. It is a true Eulima, and I believe it to be only a short, stumny form of the variable $E$. augur, Angas.

Pl. XVII., fig. 27.

\section{Cominella lineolata, Lamarek.}

This is a verv common molluse on most parts of our coast, and varies much in size, form, and colour. On the 
western side of Frederick Henry Bay, in a rather exposed situation, a short, thick-set banded form is plentiful. On December 15 th of last year, I noticed they were spawning under fairly large stones. The egg capsules formed dense masses, closely clustered together. The method adopted is for single capsules to be firmly attached at some distance apart; then three or four others are fastened to the upper edges of these, giving the combination somewhat the appearance of the growth of the prickly pear. The colour is ivory-white, the stalks whiter. I present drawings, which will give a better idea of the form than much description. The height of the single specimen is about $9 \mathrm{~mm}$., that of the cluster about $15 \mathrm{~mm}$.

Pl. XVII., figs. 28, 28a.

I can also add to our list the following seven suecies and one variety already described by various authors.

1. Arca metella, Hedley, P.L. Soc. N.S. Wales, 1917, p. 681, Pl. li., f. 36-37. About a dozen single valves taken in 100 fathoms off Cape Pillar, and a few from other places on our East and South Coasts, from 10 fathoms downwards.

2. Psendarropagia botanira, Hedley, Roy. S. N.S. Wales, 1918, Supp. p. 27. This species seems confined to our Eastern and Southern Coasts, where it takes the place of $P$. victorice, Gatliff and Gabriel, which is found in Bass Straits, and perhaps does not occur. South East of the Furneaux Group, where I found it in profusion.

3. Zalapais lissa, Suter, Cyclostrema, P. Mall. Soc., viii., p. 25, pl. ii., f. 10-11. A number of examples taken in Frederick Henry Bay from kelp roots.

4. Triphora mamillata, Verco; T. albovittata, Hedley, var. mamillata, Verco, T.R. Soc. S.A., 1909, p. 285. I recorded this in these proceedings for 1910 , p. 309, as alhovittata, but our shells are Verco's variety, which I consider is quite sufficiently distinct to be given specific rank. It has also been taken in 40 fathoms off Thouin Bay.

5. Turritella atlinsoni, Tate and May, var. medioangulata, Verco, op. cit., 1910 , p. 125 , pl. xxx., fs. 8-9. Several from 50 fathoms North of Maria Island. 


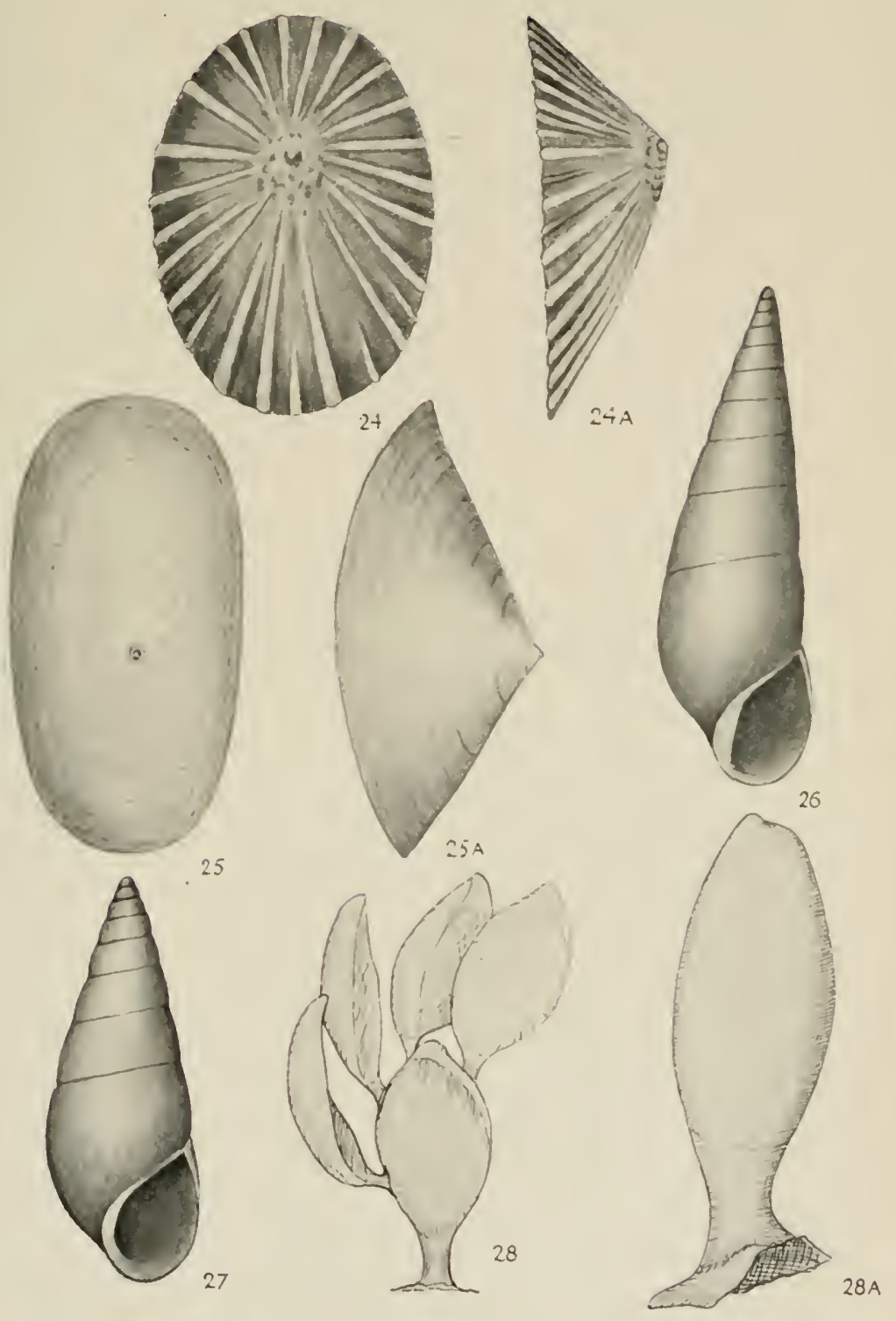


6. Essten janjucensis, Gatliff and Gabriel, Rissoa, P.R. Soc. Vic., 1913, p. 67 , pl. vili., f. 2. Three specimens from Penguin, North Coast, identified by $\mathbf{M r}$. Gabricl.

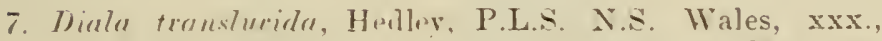
1906, p. 522, pl. xxxiii., f. 35. Tate and May, op. ril. 1901, p. 388, record this in error as J). jictn, A. Adans. A few examples liave been taken in D) Entrecasteaux Chamnel, in about 10 fatlons.

S. Sirgutntinn virtorin, Smith. P.L.S., 18s1, p. 296, pl. vii., f. 2. A number of specimens in $\mathrm{my}$ possesion were collected many years ago by $\mathbf{M r}$. E. P. Harrisson in Lake Tilerias, and are exactly the same as Victorian shells. This makes an interesting addition to our fresh water fama. 